\title{
Reduction of Pollutants of Tannery Wastewater by Using Acidic Waste Liquor
}

\author{
Md. Abdul Mottalib ${ }^{1}$, Md. Mukter Alam ${ }^{1}$, Aboni Afrose ${ }^{1}$ and \\ A. N. M. Al-Razee ${ }^{2}$ \\ ${ }^{I}$ Institute of Leather Engineering and Technology, University of Dhaka, Dhaka-1209, Bangladesh \\ ${ }^{2}$ Department of Analytical Chemistry \& Environmental Science, Central Training Institute for Chemical \\ Industries, Polash, Narsingdi-1611, Bangladesh
}

\begin{abstract}
Usually tannery effluent is characterized by strong color, high BOD, high COD, low pH and high dissolved salts. Disposal of these wastes into water body or onto land can cause irreversible damage to the environment in the vicinity. The effluents generated during liming and dyeing operations of leather processing are even more dangerous due to their high and low $\mathrm{pH}$ range, respectively. In the present work, liming and dyeing streams generated during the production of chrome tanned cow hide shoe upper were mixed together at different ratios and optimized the $p H$ range $6.72-7.61$. The effluents were mixed at different ratios without using any foreign chemicals and obtained the results $55.29 \%$ reduction of COD, $83.33 \%$ reduction of BOD, $68.11 \%$ removal of TSS, $86.31 \%$ removal of TDS, $81.84 \%$ removal of total solids, $95.77 \%$ reduction of turbidity and $86 \%$ reduction of conductance.
\end{abstract}

Keywords: Chrome tanning, Dye liquor, Lime liquor, Neutralization, Precipitation

\section{Introduction}

Tanning industry is one of the oldest industries in the world. The tannery converting raw hides and skins into leather for manufacturing articles like shoe, bag, suitcase, belt, wallet, jacket etc. and generates a large amount of solid and liquid waste [1-2] and is considered as one of the most polluting industries having potential threat to our environment. All other sectors like industry, agriculture, mining, energy, transportation, construction and consumers generate wastes as a result the amount and toxicity of waste released from industrial activities varies with the industrial processes. Again, among all the industrial wastes tannery effluents are ranked as the highest pollutants [3]. About $250 \mathrm{~kg}$ of leather is obtained as final product and $750 \mathrm{~kg}$ of solid waste together with $40,000 \mathrm{~m}^{3}$ wastewater is produced during the processing of one metric ton of raw hide [4]. From the tanning units of Hazaribagh area, roughly $15000 \mathrm{~m}^{3}$ of untreated wastes containing various chemicals and directly it goes to the river Buriganga which is a major water source for agricultural and fishing activities for the nearby population [5] and the direct discharge of this effluent from tannery has become a great environmental problem. Liming is the most important operation in the processing of leather. In this operation, the soaked hides and skins are treated with milk of lime together with the addition of sharpening agents like sulfide, cyanides, amines, markaptan etc. The spent lime liquor contains dissolved and suspended lime and colloidal proteins and their degradation products, sulfides, emulsified fatty matters and also carry a sludge composed of unreacted lime. The spent liquor has a high alkalinity, moderate BOD and high ammonia nitrogen content. Lime causes severe irritation when inhaled or placed in contact with moist skin or eyes. Inhalation cause coughing, sneezing, labored breathing. Sodium sulfide is the chemical compound which is colorless water-soluble salts and gives strong alkaline effects. When exposed to air, sodium sulfide and its hydrates form hydrogen sulfide, which smells like rotten eggs. Hydrogen sulfide is a very toxic gas which causes skin burns and increase blood pressure.

Dyeing is the process of coloring of leather by immersing them in an aqueous solution of dye which is considered as dye liquor or solution. Normally the dye liquor consists of dye, water $\&$ an auxiliary. Industrial waste water contains dyes and their intermediates. These dyes are highly toxic, persistent, mutagenic and carcinogenic disrupt the endocrine systems and are not completely removed during treatment processes. Industrial wastewater containing dyes and their intermediates is usually toxic and carcinogenic to aquatic life, causes serious environmental and esthetic problems and reduces light penetration in water which has a negative impact on photosynthesis [6]. The wastewaters of leather industries from which source the environment of Bangladesh is getting effected day by day. Because this wastewater contains pathogens (disease organisms) nutrients such as nitrogen and phosphorus, solids, chemicals from cleaners and disinfectants even hazardous substances. This waste water also changes the natural components of the rivers, lakes, sea etc. The level of $\mathrm{pH}$, $\mathrm{BOD}_{5}, \mathrm{COD}$, SS, TDS, TS, turbidity, conductance etc. are changed by this types of pollution.

To save the environment as well as to save the leather industry it is high time to think about the technological measures to combat environmental challenges from leather processing activities. So treatment of 
the tannery wastewater is a major issue for pollution control in leather processing countries. Many researchers have been done for the future sustainability of the tannery industry in respect of environmental pollution and to minimize the production of solid and liquid waste to maintain a safe environment for both aquatic life and human health [7-10]. The removal of chromium from wastewater may be accomplished by precipitation using the addition of lime and caustic soda [11]. In order to reduce chromium from tannery effluents, many researchers used different chemicals and materials like bacillus subtilis [12], magnesium oxide, three precipitation agents calcium hydroxide, sodium hydroxide and magnesium hydroxide [13], aspergillus oryzae [7], alge, fungi and bacteria [14], reverse osmosis membrane [15] employed and amberliet IR 120 resin [16]. All of the methods described above are involved additional chemicals or reagents that increase the costing of tannery effluent treatment. As a part of our continuous research on the reduction of pollutants of tannery waste water, we have shown $99.98 \% \mathrm{Cr}$ [17] and a significant amount of physiochemical properties of tannery waste water can be reduced simply by mixing two different nature of waste liquor [8]. This paper focuses on waste liquors generate from different steps of leather processing those having different $\mathrm{pH}$. In this treatment process, lime and dye liquors mixed together at different ratios to neutralize the wastewater in regarding to reduce pollution load of the tannery effluents.

\section{Materials and Method}

2.1 Collection of tannery waste liquors

Two fresh liquors namely lime liquor and dye liquor were collected from Hazaribagh tannery industrial area, Dhaka during manufacturing of chrome tanned cow hide shoe upper leather in conventional method for analysis. The $\mathrm{pH}$ of lime liquor and dye liquor were 12.50 and 4.00 respectively.

\subsection{Settlement of source liquors}

Both of the fresh liquors were mixed together at 1:2,1:3,1:4 and 1:5(v/v) ratios of lime liquor and dye liquor respectively and the mixtures were stirred for 24 hours, 2 days and 3 days at room temperature to get maximum precipitated products. The scheme of neutralization reaction of the two liquors is shown below-

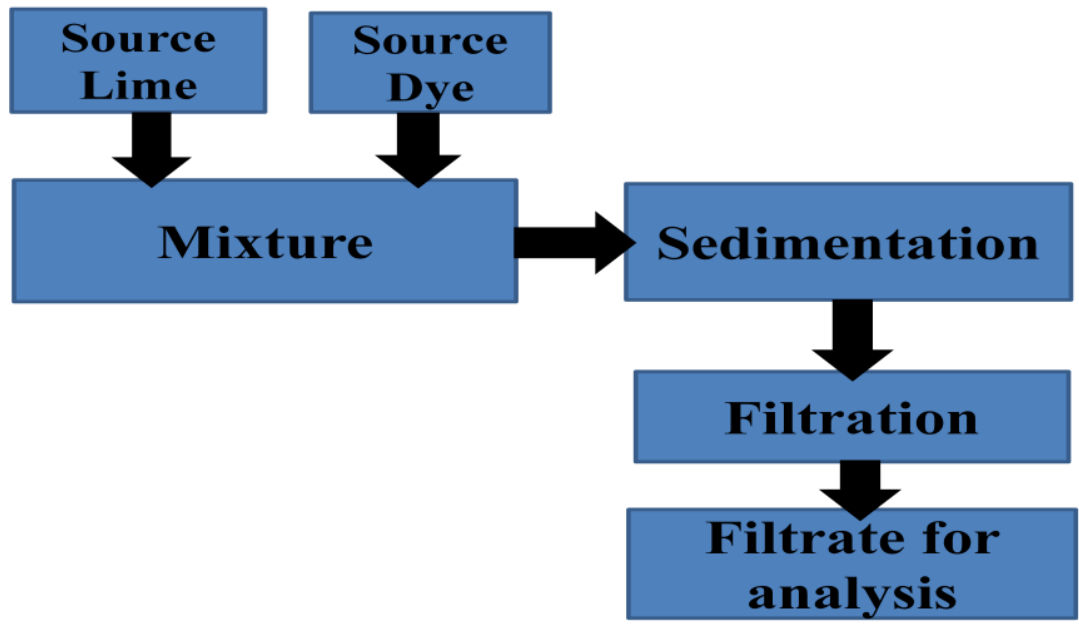

Fig. 1: Scheme of experimental layout

\subsection{Optimization of the following $\mathrm{pH}$ values}

\section{Results And Discussion}

The $\mathrm{pH}$ of source lime and dye liquors were measured immediately after collection of samples from tannery. The source lime liquor and dye liquor were mixed at different ratios and the mixtures were stirred for different definite time for precipitation. In this regards four different ratios of lime liquor and dye liquor were considered for stirring at different times such as 24 hours, 2 days and 3 days to get neutralization point and as well as maximum precipitation of pollutants. After 24 hours, 2 days and 3 days stirring the reaction mixture were allowed to leave for a couple of hours for precipitation. Then the reaction mixtures were filtered. The filtrates of different ratios were analyzed. The physiochemical properties like $\mathrm{pH}, \mathrm{COD}, \mathrm{BOD}$, TSS, TDS, TS, Conductance and Turbidity were measured. The obtained results are described in this paper. 
Optimization of the following $\mathrm{pH}$ values

The $\mathrm{pH}$ of different ratios is shown in Table 1.

Table 1: Mixing ratios and the optimized $\mathrm{pH}$ of the liquors

\begin{tabular}{|c|c|c|}
\hline Sample & Ratio & $\mathrm{pH}$ \\
\hline Lime: Dye (L: D) & $1: 2$ & 9.52 \\
\hline Lime: Dye (L: D) & $1: 3$ & 8.00 \\
\hline Lime: Dye (L: D) & $1: 4$ & 7.61 \\
\hline Lime: Dye (L: D) & $1: 5$ & 6.72 \\
\hline
\end{tabular}

The $\mathrm{pH}$ value of the collected liquors were 12.50 (Lime) and 4.00 (Dye). After $24 \mathrm{hrs}$ stirring and then filtration, the $\mathrm{pH}$ of filtrates was measured. The $\mathrm{pH}$ value of the ratios 1:2,1:3,1:4 and 1:5 of lime and dye were obtained 9.52, 8.00, 7.61 and 6.72 respectively. Since the $\mathrm{pH}$ value of wastewater $6.72-7.61$ are within dischargeable limit, the ratio 1: 4 and 1:5 of lime and dye liquors were stirred for 2 and 3 days to get maximum reduction of pollutants.

The COD of fresh lime liquor and fresh dye liquor were found to be 16320 and $4500 \mathrm{mg} / \mathrm{L}$ respectively. The COD values for mixtures of different ratios and at different duration are shown in Table 2 .

Table 2: COD values of lime and dye (L/D) mixed liquor at different ratios after settlement

\begin{tabular}{|c|c|c|c|c|c|c|c|c|c|}
\hline \multirow{2}{*}{$\begin{array}{c}\text { Sample } \\
\text { Name }\end{array}$} & \multicolumn{3}{|c|}{24 hours } & \multicolumn{3}{c|}{2 days } & \multicolumn{3}{c|}{3 days } \\
\cline { 2 - 9 } & $\mathrm{pH}$ & $\begin{array}{c}\text { COD } \\
(\mathrm{mg} / \mathrm{L})\end{array}$ & $\begin{array}{c}\% \text { of } \\
\text { reduction }\end{array}$ & $\mathrm{pH}$ & $\begin{array}{c}\mathrm{COD} \\
(\mathrm{mg} / \mathrm{L})\end{array}$ & $\begin{array}{c}\% \text { of } \\
\text { reduction }\end{array}$ & $\mathrm{pH}$ & $\begin{array}{c}\text { COD } \\
(\mathrm{mg} / \mathrm{L})\end{array}$ & $\begin{array}{c}\% \text { of } \\
\text { reduction }\end{array}$ \\
\hline (L: D) $1: 2$ & 9.52 & 13298 & $18.52 \%$ & - & - & - & - & - & - \\
\hline (L: D) $1: 3$ & 8.00 & 11088 & $32.06 \%$ & - & - & - & - & - & - \\
\hline (L: D) $1: 4$ & 7.61 & 10272 & $37.06 \%$ & 7.55 & 9888 & $39.41 \%$ & 7.50 & 9120 & $44.12 \%$ \\
\hline (L: D) $1: 5$ & 6.72 & 9216 & $43.53 \%$ & 6.60 & 8208 & $49.71 \%$ & 6.50 & 7296 & $55.29 \%$ \\
\hline
\end{tabular}

The above observations revealed that a significant amount of COD value reduced when lime and dye liquor were mixed together. After $24 \mathrm{hrs}$ stirring, the COD values at ratios 1:2, 1: 3, 1: 4 and 1: 5 were 13298 $\mathrm{mg} / \mathrm{L}, 11088 \mathrm{mg} / \mathrm{L}, 10272 \mathrm{mg} / \mathrm{L}$ and $9216 \mathrm{mg} / \mathrm{L}$ respectively. This reduction is due to precipitate formation caused by acid-base reaction occurred between lime and dye liquor. And there is a clear correlation between the $\mathrm{pH}$ and the COD value of effluent mixtures. The mixture 1: 5 having $\mathrm{pH}$ closer to neutrality and has the lowest $\mathrm{COD}$ value. Increasing the mixing time, formation of precipitation increased and the $\mathrm{pH}$ value reduced gradually. With the decrease of $\mathrm{pH}$ of these mixtures more pollutants reduced as indicated by the decrease in COD values. The reduction efficiency of COD after 24 hours, 2 and 3 days were 37.06, 39.41 and $44.12 \%$, respectively for 1: 4 ratio while those values were 53, 49.71 and $55.29 \%$ respectively for 1: 5 ratio.

The $\mathrm{BOD}_{5}$ of fresh lime and dye liquor were found to be 3000 and $1000 \mathrm{mg} / \mathrm{L}$ respectively. The $\mathrm{BOD}_{5}$ values for mixtures of different ratios and at different times are shown in Table 3.

Table 3: $\mathrm{BOD}_{5}$ values of lime and dye mixed liquor at different ratios after settlement

\begin{tabular}{|c|c|c|c|c|c|c|c|c|c|}
\hline \multirow{2}{*}{$\begin{array}{c}\text { Sample } \\
\text { ratios }\end{array}$} & \multicolumn{3}{|c|}{24 hours } & \multicolumn{3}{c|}{2 days } & \multicolumn{3}{c|}{3 days } \\
\cline { 2 - 9 } & $\mathrm{pH}$ & $\begin{array}{c}\mathrm{BOD}_{5} \\
(\mathrm{mg} / \mathrm{L})\end{array}$ & $\begin{array}{c}\% \text { of } \\
\text { reduction }\end{array}$ & $\mathrm{pH}$ & $\begin{array}{c}\mathrm{BOD}_{5} \\
(\mathrm{mg} / \mathrm{L})\end{array}$ & $\begin{array}{c}\% \text { of } \\
\text { reduction }\end{array}$ & $\mathrm{pH}$ & $\begin{array}{c}\mathrm{BOD}_{5} \\
(\mathrm{mg} / \mathrm{L})\end{array}$ & $\begin{array}{c}\% \text { of } \\
\text { reduction }\end{array}$ \\
\hline (L: D) $1: 2$ & 9.52 & 2250 & $25.00 \%$ & - & - & - & - & - & - \\
\hline (L: D) $1: 3$ & 8.00 & 1890 & $38.33 \%$ & - & - & - & - & - & - \\
\hline (L: D) $1: 4$ & 7.61 & 1610 & $46.33 \%$ & 7.55 & 1150 & $61.66 \%$ & 7.50 & 850 & $71.66 \%$ \\
\hline (L: D) $1: 5$ & 6.72 & 1450 & $51.66 \%$ & 6.60 & 800 & $73.33 \%$ & 6.50 & 500 & $83.33 \%$ \\
\hline
\end{tabular}

The $\mathrm{BOD}_{5}$ values of the mixtures were decreased significantly like COD. At those ratios, the $\mathrm{BOD}_{5}$ values were found $2250 \mathrm{mg} / \mathrm{L}, 1890 \mathrm{mg} / \mathrm{L}, 1610 \mathrm{mg} / \mathrm{L}$ and $1450 \mathrm{mg} / \mathrm{L}$ respectively after 24 hours stirring at room temperature. The reduction of $\mathrm{BOD}_{5}$ after 24 hours, 2 and 3 days were $46.33 \%, 61.66 \%$ and $71.66 \%$ respectively for 1: 4 ratios while in 1: 5 ratios were $51.66 \%, 73.33 \%$ and $83.33 \%$ respectively.

DOI: $10.9790 / 2402-1103012833 \quad$ www.iosrjournals.org $\quad 30 \mid$ Page


Total suspended solid (TSS) of fresh lime and dye liquor were measured and obtained the values were 13850 and $3703 \mathrm{mg} / \mathrm{L}$ respectively. The spent lime liquor contains suspended lime and colloidal proteins and their degradation products, emulsified fatty matters and that is why its TSS value is much more higher than dye liquor. The TSS values for mixtures of different ratios and at different times are shown in Table 4.

Table 4: TSS values of lime and dye mixed liquor at different ratios after settlement

\begin{tabular}{|c|c|c|c|c|c|c|c|c|c|}
\hline \multirow{2}{*}{$\begin{array}{c}\text { Sample } \\
\text { ratios }\end{array}$} & \multicolumn{4}{|c|}{24 hours } & \multicolumn{3}{c|}{2 days } & \multicolumn{3}{c|}{3 days } \\
\cline { 2 - 10 } & $\mathrm{pH}$ & $\begin{array}{c}\text { TSS } \\
(\mathrm{mg} / \mathrm{L})\end{array}$ & $\begin{array}{c}\% \text { of } \\
\text { reduction }\end{array}$ & $\mathrm{pH}$ & $\begin{array}{c}\text { TSS } \\
(\mathrm{mg} / \mathrm{L})\end{array}$ & $\begin{array}{c}\% \text { of } \\
\text { reduction }\end{array}$ & $\mathrm{pH}$ & $\begin{array}{c}\text { TSS } \\
(\mathrm{mg} / \mathrm{L})\end{array}$ & $\begin{array}{c}\% \text { of } \\
\text { reduction }\end{array}$ \\
\hline (L: D) $1: 2$ & 9.52 & 5900 & $57.40 \%$ & - & - & - & - & - & - \\
\hline (L: D) $1: 3$ & 8.00 & 5726 & $58.67 \%$ & - & - & - & - & - & - \\
\hline (L: D) $1: 4$ & 7.61 & 5159 & $62.75 \%$ & 7.55 & 5018 & $63.77 \%$ & 7.50 & 4860 & $64.91 \%$ \\
\hline (L: D) $1: 5$ & 6.72 & 4820 & $65.19 \%$ & 6.60 & 4610 & $66.71 \%$ & 6.50 & 4417 & $68.11 \%$ \\
\hline
\end{tabular}

After 24 hours stirring, the observations showed that the TSS value for the ratios 1:2, 1: 3, 1: 4 and 1: 5 were $5900,5726,5159$ and $4820 \mathrm{mg} / \mathrm{L}$ as well as the \% of reductions of TSS for the same ratios were 57.40, 58.67, 62.75 and $65.19 \%$ respectively. The maximum reduction of TSS was found $68 \%$ in ratio 1: 5 after 3 days stirring.

The summery of TDS values of the above ratios are shown in the Table 5.

Table 5: TDS values of lime and dye mixed liquor at different ratios after settlement

\begin{tabular}{|c|c|c|c|c|c|c|c|c|c|}
\hline \multirow{2}{*}{$\begin{array}{c}\text { Sample } \\
\text { ratios }\end{array}$} & \multicolumn{5}{|c|}{24 hours } & \multicolumn{3}{c|}{2 days } & \multicolumn{3}{c|}{3 days } \\
\cline { 2 - 10 } & $\mathrm{pH}$ & $\begin{array}{c}\text { TDS } \\
(\mathrm{mg} / \mathrm{L})\end{array}$ & $\begin{array}{c}\% \text { of } \\
\text { reduction }\end{array}$ & $\mathrm{pH}$ & $\begin{array}{c}\text { TDS } \\
(\mathrm{mg} / \mathrm{L})\end{array}$ & $\begin{array}{c}\% \text { of } \\
\text { reduction }\end{array}$ & $\mathrm{pH}$ & $\begin{array}{c}\text { TDS } \\
(\mathrm{mg} / \mathrm{L})\end{array}$ & $\begin{array}{c}\% \text { of } \\
\text { reduction }\end{array}$ \\
\hline (L: D) $1: 2$ & 9.52 & 23265 & $45.28 \%$ & - & - & - & - & - & - \\
\hline (L: D) $1: 3$ & 8.00 & 18148 & $57.31 \%$ & - & - & - & - & - & - \\
\hline (L: D) $1: 4$ & 7.61 & 12159 & $71.40 \%$ & 7.55 & 10350 & $75.66 \%$ & 7.50 & 8207 & $80.70 \%$ \\
\hline (L: D) $1: 5$ & 6.72 & 11896 & $72.02 \%$ & 6.60 & 7060 & $83.39 \%$ & 6.50 & 5820 & $86.31 \%$ \\
\hline
\end{tabular}

The TDS value reduced as TSS when both the liquor was mixed at different ratios and at different duration. The TDS of fresh lime and dye liquor were $42515 \mathrm{mg} / \mathrm{L}$ and $13985 \mathrm{mg} / \mathrm{L}$ respectively. The TDS value of the filtrate of the ratios 1:2, 1:3, 1: 4 and 1: 5 were measured and found the values were $23265 \mathrm{mg} / \mathrm{L}, 18148$ $\mathrm{mg} / \mathrm{L}, 12159 \mathrm{mg} / \mathrm{L}$ and $11896 \mathrm{mg} / \mathrm{L}$ respectively. The $86 \%$ of TDS can be reduced in 1: 5 ratios of lime and dye liquor after 3 days stirring. With the decrease of $\mathrm{pH}$ of these mixtures more pollutants reduced as indicated by the decrease in TDS.

The TS of fresh lime and dye liquors were found to be 56365 and $17688 \mathrm{mg} / \mathrm{L}$ respectively. The TS values for mixtures of different ratios and at different duration are shown in Table 6.

Table 6: TS values of lime and dye mixed liquor at different ratios after settlement

\begin{tabular}{|c|c|c|c|c|c|c|c|c|c|}
\hline \multirow{2}{*}{$\begin{array}{c}\text { Sample } \\
\text { Name }\end{array}$} & \multicolumn{3}{|c|}{24 hours } & \multicolumn{4}{c|}{2 days } & \multicolumn{3}{c|}{3 days } \\
\cline { 2 - 10 } & $\mathrm{pH}$ & $\begin{array}{c}\mathrm{TS} \\
\mathrm{mg} / \mathrm{L})\end{array}$ & $\begin{array}{c}\% \text { of } \\
\text { reduction }\end{array}$ & $\mathrm{pH}$ & $\begin{array}{c}\mathrm{TS} \\
(\mathrm{mg} / \mathrm{L})\end{array}$ & $\begin{array}{c}\% \text { of } \\
\text { reduction }\end{array}$ & $\mathrm{pH}$ & $\begin{array}{c}\mathrm{TS} \\
(\mathrm{mg} / \mathrm{L})\end{array}$ & $\begin{array}{c}\% \text { of } \\
\text { reduction }\end{array}$ \\
\hline (L: D) $1: 2$ & 9.52 & 29165 & $48.26 \%$ & - & - & - & - & - & - \\
\hline (L: D) $1: 3$ & 8.00 & 23874 & $57.64 \%$ & - & - & - & - & - & - \\
\hline (L: D) $1: 4$ & 7.61 & 17318 & $69.28 \%$ & 7.55 & 15368 & $72.73 \%$ & 7.50 & 13067 & $76.82 \%$ \\
\hline (L: D) $1: 5$ & 6.72 & 16716 & $70.34 \%$ & 6.60 & 11670 & $79.30 \%$ & 6.50 & 10237 & $81.84 \%$ \\
\hline
\end{tabular}

The above observations show that the TS value of the filtrate of the ratios 1:2,1:3,1:4 and 1:5 were $29165,23874,17318$ and $16716 \mathrm{mg} / \mathrm{L}$ respectively after 24 hours stirring at room temperature. The reduction efficiency of TS of 1:5 ratio is better than that of 1:4 ratio of lime and dye liquor. The above results revealed that the significant amount (70.34\%) of TS was reduced after 24 hours of stirring at room temperature in 1:5 ratios. Further stirring up to next 2 days $82 \%$ TS can be reduced. 
The turbidity value of fresh lime and dye liquors were found to be 1.5 NTU and 70.9 NTU respectively. The turbidity values for different ratio are given below in figure 2. Turbidity of the reaction mixtures of ratios 1:2,1:3,1: 4 and 1: 5 were found 41.0, 8.5, 2.8 and 3.0 NTU respectively after 24 hours stirring. Here the turbidity value is little bit increased in 1: 5 because of the high turbidity value of dye liquor. During acid-base reaction the more dye liquor remain in the mixture.

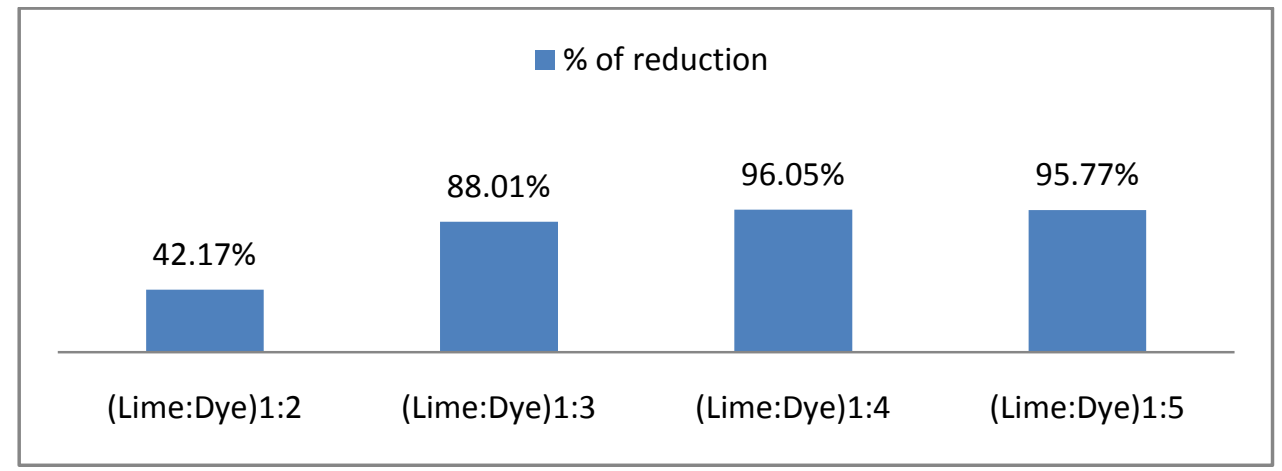

Figure 2: \% of reduction of Turbidity of lime and dye mixed liquor at different ratios.

The conductance of fresh lime and dye liquors were found $60.7 \mathrm{mS} / \mathrm{cm}$ and $5.12 \mathrm{mS} / \mathrm{cm}$ respectively. The status of conductance value of mixtures of different ratios at different time duration is given in figure 3 . The conductance values of the filtrate of the ratios 1:2,1:3,1:4 and 1: 5 of lime and dye liquor were 16.06, 14.10, 12.78 and $8.51 \mathrm{mS} / \mathrm{cm}$ respectively after $24 \mathrm{hrs}$ stirring. With the decrease of $\mathrm{pH}$ of these mixtures more pollutants reduced as indicated by the decrease in conductance values like other physicochemical parameters. After 24 hours the reductions of conductance were $88.89 \%$ and $92.6 \%$ respectively at 1: 4 and 1: 5 ratios. So, it can be concluded that the $\mathrm{pH}$ is reduced to neutral level; the value of conductance is reduced significantly.

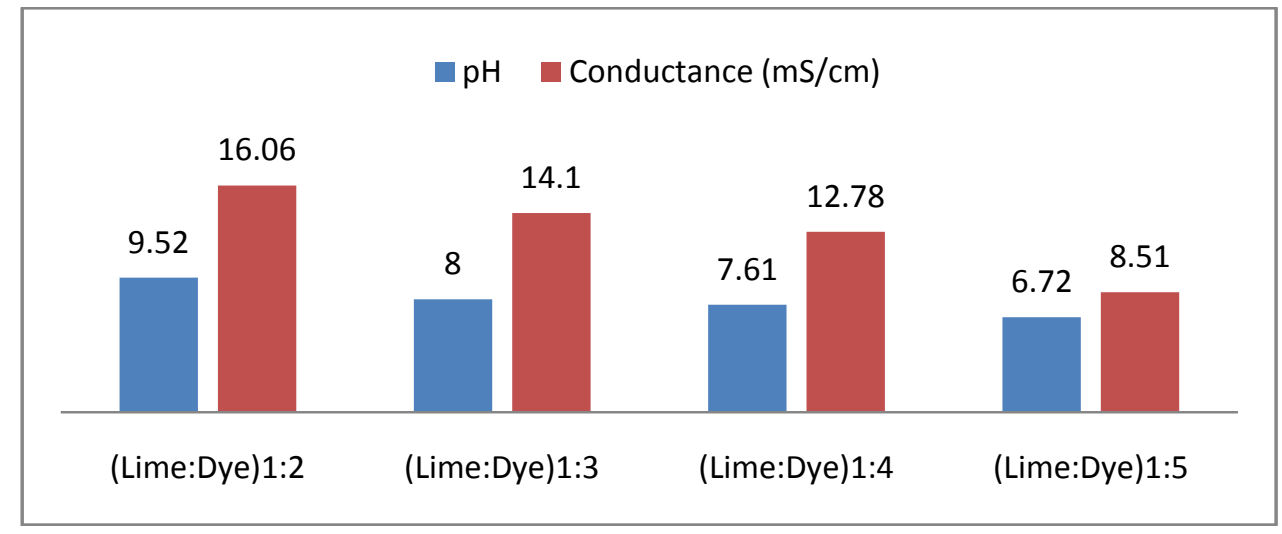

Figure 3: \% of reduction of conductance of lime and dye mixed liquor at different ratios.

\section{Conclusion}

The effluents generated during liming and dyeing operations of leather processing are very harmful for aquatic life as well as for total environment due to their high and low $\mathrm{pH}$ range respectively. In this paper tried to minimize the environmental impact of tannery effluent focusing on lime and dyeing streams and they were treated to minimize their pollution load by an appropriate, simple and economically viable method with an objective of introducing some new aspects of tannery effluent treatment especially for tanneries of Bangladesh. The operations settlement, close to a neutral $\mathrm{pH}$ range causes a remarkable reduction of COD, BOD, TSS, TDS, and turbidity and conductance value. This reduction is due to precipitate formation caused by acid-base reaction occurred between lime and dye liquor. So it can be concluded that this operations techniques could be an effective options for the treatment of lime and dye liquors in very economical way to fulfill the tannery effluent standard for discharge. 


\section{References}

[1] J. Kanagaraj, K. C. Velappan, N. K. Chandra Babu and S. Sadulla, Solid waste generation in the leather industry and its utilization for cleaner environment, J. Sci. \& Ind.; 65, 2006, 541-548.

[2] G. Sekaran, S. Swarnalatha and T. Srinivasulu, Solid waste management in leather sector, J. Design and Manufacturing Technologies; 1(1), 2007, 47-52.

[3] M. R. Azorn, K. Mahmud, S. M. Yahya, A. Sontu, and S. B. Himon, Environmental Impact Assessment of Tanneries: A Case Study of Hazaribag in Bangladesh, International Journal of Environmental Science and Development; 3(2), 2012, $152-156$.

[4] S. Hüffer and T. Taeger, Sustainable leather manufacturing a topic with growing importance, J. Am. Leather Chem. Assoc.; 99(10), 2004, 423-428.

[5] UNIDO: Regional programme for pollution control in the tanning industry in south-east Asia: Chrome balance in leather processing; 2000.

[6] Adeyi, Ayanda, Olutona, Ganiyu, Adsorption kinetics and intra-particulate diffusivity of aniline blue dye onto activated plantain peels carbon, Chemical Science Transactions; 2 (1), 2013, 294 - 300.

[7] M. N. Sepehr, S. Nasseri, M. M. Assadi, and K. Yaghmaian, Chromium bioremoval from tannery industries effluent by aspergillus oryzae. Iran. J. Environ. Health Sci., Eng.; 2(4), 2005, 273-279.

[8] M. A. Mottalib, T. Khan and M. N. Abser, A Simple Effective Treatment of Tannery Effluents, J. of Bangladesh Academy of Sciences; 38(2), 2014, 235-239.

[9] M. M. Barbooti, M. A. Zablouk, and U. A. Al-zubaidi, Recovery of chromium from waste tanning liquors by magnesium oxide, Int. J. Ind. Chem; 1(1), 2010, 29-38.

[10] J. Buljan, and I. Kral, Introduction to treatment of tannery effluents, UNIDO technical paper; 2011.

[11] M. M. Barbooti, B. A. Abid and N. M. Al-Shuwalki, Removal of heavy metals using chemicals, J. Engineer. Technol.; 29(3), 2011, 595-612.

[12] S. S. Adeel, A. Wajid, S. Hussain, F. Malik, Z. Sami, I. U. Haq, A. Hameed and R. A. Channa, Recovery of chromium from tannery wastewater by use of bacillus subtilis in Guranwala. Pakistan. Journal of Pharmacy and Biological Sciences; 2(2), 2012, 36-45.

[13] A. Esmaeili, A. Mesdaghi, and R. Vazirinejad, Chromium (III) removal and recovery from tannery wastewater by precipitation process, American Journal of Applied Sciences; 2(10), 2005, 1471-1473.

[14] V. M. Beleza, R. A. Boaventura and M. F. Almeida, Kinetics of chromium removal from spent tanning liquors using acetylene production sludge, Environ. Sci. Technol.; 35, 2001, 4379-4383.

[15] A. I. Hafez, M. S. El-Manharawy and M. A. Khedr, RO membrane removal of untreated chromium from spending tanning effluent. A pilot scale study, part 2, Desalination, 14, 2002, 237-242.

[16] P. Meshram, S. K. Sahu, B. D. Pandey, V. Kumer and T. R. Mankhand, Removal of chromium (III) from the waste solution of an Indian tannery by amberlite IR 120 resin, Int. J. Nonferrous Metallurgy; 1, 2012, 32-41.

[17] M. A. Mottalib, S. H. Samoal, M. S. Islam, M. N. Alam, M. N. Abser, Removal of chromium from tannery wastewater by tannery lime liquor; a very cost effective method, Int. J. of Current Research; 7, 2015, 16795-16798. 